\title{
Dorota Matulka
}

\section{Turystyka medyczna \\ - szansą na poprawę efektywności w polskim systemie ochrony zdrowia}

\section{Streszczenie}

Celem artykułu jest udzielenie odpowiedzi na pytanie, czy turystyka medyczna o charakterze wyjazdowym może stać się sposobem na problemy dostępności do usług medycznych w polskim systemie ochrony zdrowia? Zakres pracy - obok zobrazowania odczuć samych mieszkańców Polski dotyczących trudności z otrzymaniem świadczeń medycznych - obejmuje także m.in.: prezentację dostępnych rozwiązań dla polskiego obywatela w kwestii wyjazdów na leczenie zagraniczne, rozważania dotyczące wpływu oczekiwania w kolejce do specjalisty na sytuację gospodarczą kraju, jak i samej jednostki ludzkiej. W artykule wykorzystano dane statystyczne pochodzące z różnych ośrodków badawczych, a także dokonano studium literatury.

Słowa kluczowe: ochrona zdrowia, turystyka medyczna, dostępność świadczeń medycznych, dyrektywa transgraniczna.

\section{Medical Tourism - An Opportunity to Improve Efficiency in the Polish Healthcare System}

\begin{abstract}
The aim of this article is to answer the question whether outbound medical tourism can be a remedy for the problems of accessibility of medical services in the Polish healthcare system. The scope of the text - besides describing Polish residents' feelings about the difficulty in obtaining medical services - also includes the presentation of available solutions (in terms of foreign treatment) for Polish citizens and considerations about the effect that waiting in a queue to a specialist has

1 Dorota Matulka - mgr, doktorantka, Wydział Zarządzania Uniwersytetu Warszawskiego, ul. Szturmowa 1/3, 02-678 Warszawa, e-mail: matulka.dorota@gmail.com; ORCID: 0000-0001-6346-4302.
\end{abstract}


on the economic situation of the country as well as on the individual human. The article uses statistical data from various research centres and contains a study of literature.

Keywords: healthcare, medical tourism, availability of medical services, cross-border healthcare directive.

\section{Wprowadzenie}

Funkcjonowanie systemów ochrony zdrowia stanowi przedmiot analiz naukowych, głównie ze względu na wciąż pojawiające się nowe wyzwania współczesnego świata. Wzrost mediany wieku ludności, narastające koszty procedur medycznych oraz zwiększające się oczekiwania pacjentów zmuszają do dokonywania nieustannych zmian w zakresie poprawy warunków leczenia i efektywności ekonomicznej (Nojszewska, 2011, s. 49-90). Na stan zdrowia człowieka wpływa wiele czynników w dużej mierze zależnych od decyzji władz państwa, tj. np.: warunki gospodarcze, wydatki publiczne przeznaczane na ten cel oraz od prawidłowego gospodarowania środkami przez decydentów, którym funkcja ta została powierzona. Właściwie działający system ochrony zdrowia winien być priorytetem państw funkcjonujących zgodnie z ideą welfare state. Niestety, duża liczba krajów europejskich, szczególnie położonych w obszarze środkowo-wschodnim, nie potrafi poradzić sobie z licznymi problemami, z których najważniejszy to utrudniony dostęp do świadczeń medycznych. Powszechnym zjawiskiem m.in. w Polsce jest oczekiwanie pacjentów w długich kolejkach do lekarzy specjalistów, czy też na zabiegi medyczne, finansowane ze środków publicznych. Propozycje rozwiązania tego problemu często koncentrują się - z jednej strony na zwiększeniu finansowania ochrony zdrowia w postaci znaczącego podniesienia składki zdrowotnej, na którą nie stać polskich obywateli z powodów niskich dochodów. Z drugiej strony - obejmują wariant zmiany modelu funkcjonowania systemu opieki zdrowotnej w kierunku rozwiązania opierającego się na modelu Beveridge'a, aby ograniczyć głównie koszty, tzw. bramki, polegającej na konieczności filtrowania świadczeniobiorców na tych, którzy mają prawo do nabywania świadczeń finansowanych ze środków publicznych i takich, którzy takiej możliwości nie mają. Niestety, również to rozwiązanie nie gwarantuje osiągnięcia sukcesu, patrząc na przykłady innych państw europejskich, a ponadto w dłuższej perspektywie będzie wymuszało prawdopodobnie podniesienie podatków. Jednak kilka lat temu pojawiła się nowa alternatywa w postaci turystyki medycznej o charakterze wyjazdowym, określanej jako świadomy i niewymuszony wyjazd poza miejsce stałego zamieszkania w celu nabycia świadczenia zdrowotnego 
za granicą w placówce zbiorowej opieki medycznej o charakterze publicznym lub prywatnym, które ingeruje w organizm człowieka. Wyjazd ten może być połączony z tradycyjnym wypoczynkiem, zwiedzaniem i regeneracją sił fizycznych oraz psychicznych. Powstaje więc pytanie, czy turystyka medyczna może złagodzić problemy związane z dostępnością do świadczeń w polskim systemie ochrony zdrowia?

\section{Funkcjonowanie systemu ochrony zdrowia w Polsce a dostępność do świadczeń}

Finansowanie polskiego systemu ochrony zdrowia jest prowadzone głównie w oparciu o składkę zdrowotną, którą tworzą środki pochodzące zarówno od pracownika, jak i pracodawcy (odprowadzającego część składki do ZUS). Większość obywateli ma prawo do nabywania usług zdrowotnych opłacanych ze środków publicznych z tytułu zatrudnienia (składka w wysokości 9\% miesięcznego wynagrodzenia w 2017 roku wpływająca do NFZ w przypadku umowy o pracę). Dostępny zakres świadczeń w ramach płaconej kwoty umieszczono w tzw. koszyku świadczeń gwarantowanych, który obejmuje wyłącznie podstawowe usługi zdrowotne.

Rysunek 1. Wydatki publiczne na ochronę zdrowia (przedstawione w USD per capita oraz \% PKB) w 2010 i 2015 roku

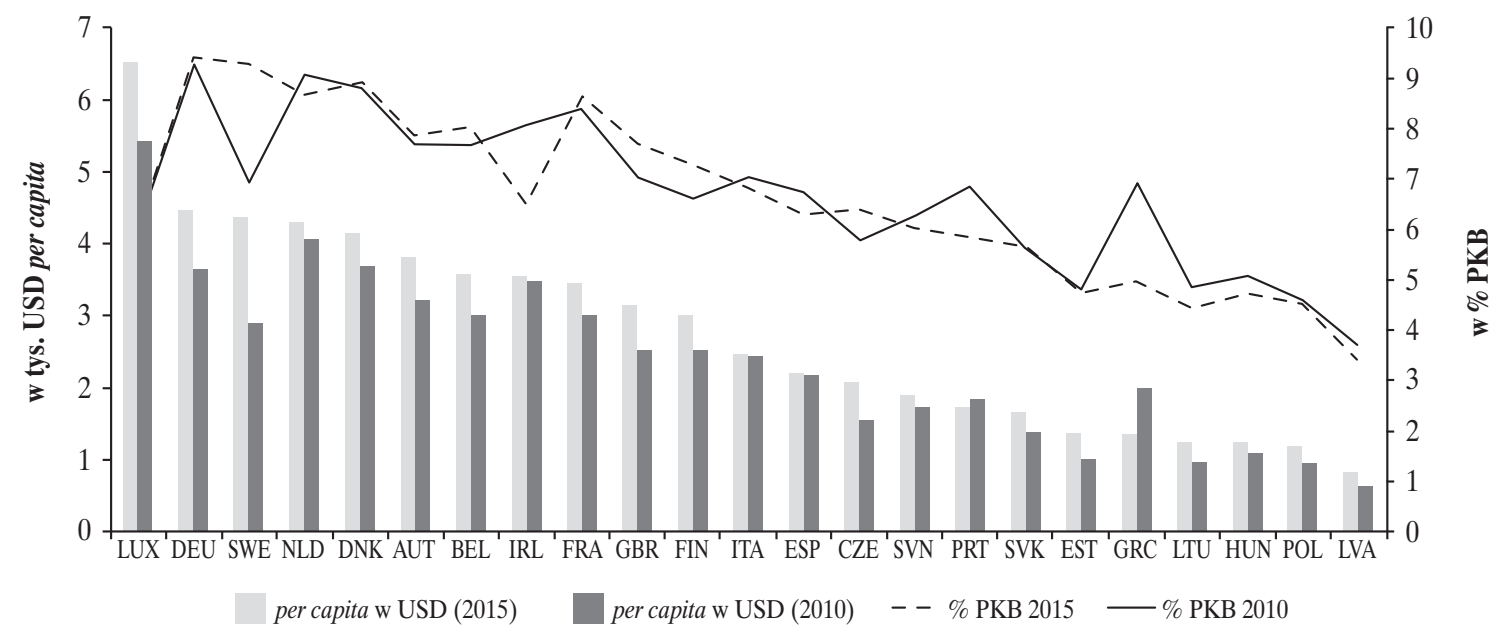

Źródło: opracowanie własne na podstawie danych OECD.

Polskie finansowanie (publiczne) służby zdrowia jest jednym z najniższych w Unii Europejskiej. Na ochronę zdrowia w Polsce w 2015 roku przeznaczono 4,5\% PKB (1,2 tys. USD per capita). W porównaniu np. do Niemiec 
wartość ta była niższa o ponad 3,3 tys. USD w przeliczeniu na jednego mieszkańca. Pomiędzy latami 2010 i 2015, publiczne środki przeznaczane na leczenie polskich pacjentów wzrosły o $25 \%$ w przypadku przelicznika per capita i o 0,1 punktu procentowego PKB. Lecz zmiana ta w porównaniu do większości państw członkowskich UE nadal wydaje się być niewystarczająca.

Ta sytuacja w znaczący sposób wpływa na usługi medyczne poprzez: niskie wynagrodzenia personelu medycznego, jego liczebność, brak postępu w zakresie jakości sprzętu medycznego, który jest ważny ze względu na nowe wyzwania przed którymi stoi współczesny świat, zmniejszającą się rentowność placówek medycznych (najczęstszym problemem zgłaszanym przez środowisko medyczne są niskie kontrakty z NFZ), ich zaopatrzenie i efektywność leczenia. W tej sytuacji - co zauważa pacjent - to tylko niewydolnie działająca służba zdrowia, której symbolem od wielu lat stały się długie kolejki do świadczeń medycznych. Lecz z czego one wynikają? Oczywiście, kwestia finansowania nie jest jedyną przyczyną ograniczonego dostępu do świadczeń medycznych, ale można traktować ją jako jeden z ważniejszych (pośrednich) czynników. Istotne jest tu także np. zachowanie samych pacjentów, którzy rezerwują wizyty „na wszelki wypadek”. W efekcie często rezygnują ze świadczenia - i co najgorsze - nie uprzedzają o swojej nieobecności personelu medycznego. Według jednego z dyrektorów warszawskiej przychodni: $z$ darza się, że na 20 pacjentów zapisanych do jednego specjalisty potowa nie przychodzi i nie uprzedza, że ich nie będzie. Dla placówki taka „pusta” wizyta to strata, bo jeśli nie byto chorego, nie ma też pieniędzy z Funduszu (Pochrzęst-Motyczyńska, 2016). Ale należy pamiętać, że każdy człowiek z natury postępuje pragmatycznie. Pacjent zawsze będzie poszukiwał szybkiego rozwiązania swojego problemu. Jednak takiego, które będzie cechowała odpowiednia dla niego jakość. Dlatego często zapisuje się u świadczeniodawców mogących wykonać usługę względnie szybko z zachowaniem akceptowalnego poziomu jakości. Mając już pewne miejsce u specjalisty może poszukiwać lepszych możliwości. W momencie znalezienia usługi, która (w jego odczuciu) będzie charakteryzowała się lepszą jakością - zmienia swoją decyzję, zapominając o rezygnacji z poprzedniej alternatywy (niejednokrotnie nie z powodu złych intencji, ale np. przytłoczenia swoim problemem, jakim jest choroba). Oczywiście, nie mam zamiaru usprawiedliwiać tu nieodwoływania zarezerwowanych wizyt, ale zwrócić uwagę na to, że nie jest to wyłącznie wina samych pacjentów, lecz także niezintegrowanego systemu, pozwalającego na nieefektywne wykorzystanie środków publicznych. 
Rysunek 2. Liczba lekarzy i pielęgniarek przypadająca na 1 tys. mieszkańców w 2014 roku

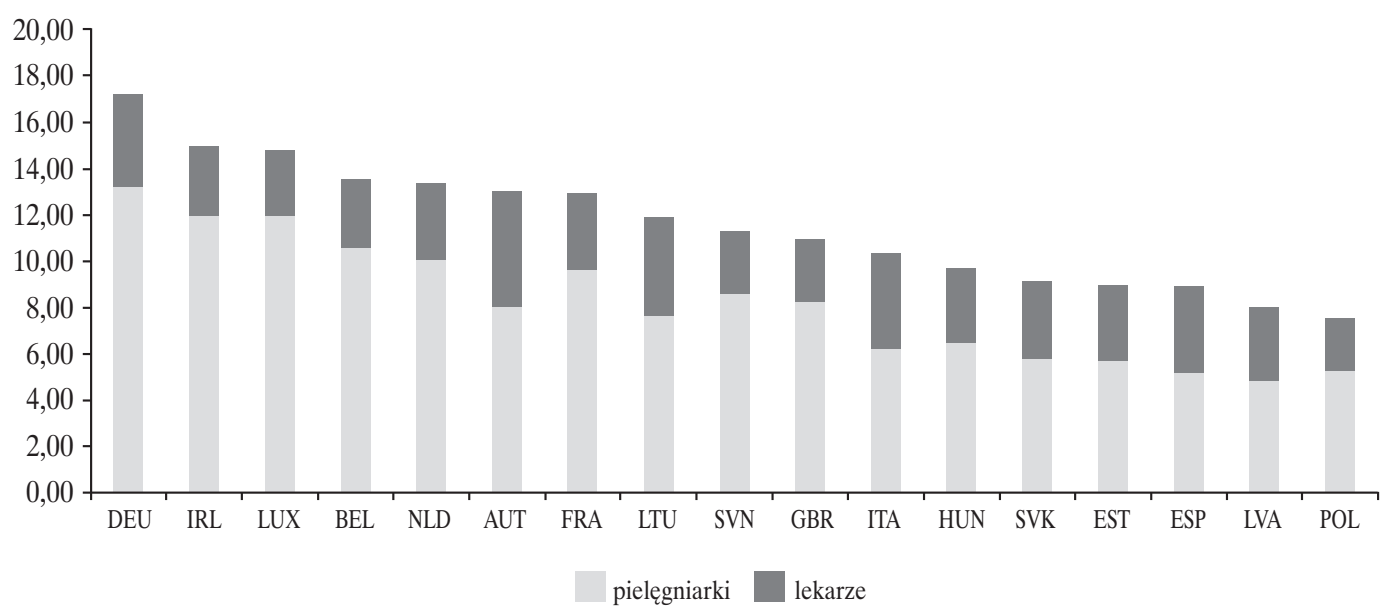

Źródło: opracowanie własne na podstawie danych OECD.

Kolejną kwestią, na którą należy zwrócić uwagę, jest aspekt zasobów. Zestawiając na rysunku 2 liczbę pielęgniarek i lekarzy przypadających na 1 tys. mieszkańców możemy wywnioskować, że Polska dysponuje jednym z najniższych wskaźników liczebności personelu medycznego w UE. Zajmuje bowiem ostatnie miejsce wśród wszystkich wymienionych krajów.

Porównując wyniki badania nt. Opinie o funkcjonowaniu systemu opieki zdrowotnej z 2014 i 2016 roku, w którym zapytano polskich świadczeniobiorców, czy zgadzają się ze stwierdzeniem, że jeśli pacjent tego potrzebuje, to może latwo dostać się na wizytę do specjalisty. W 2014 roku zaledwie $11 \%$ badanych wyraziło akceptację tego stwierdzenia, aż 85\% - zaprzeczyło (CBOS, 2014). Po upływie dwóch lat, w 2016 roku ten procentowy udział przedstawiał jeszcze bardziej niepokojące wyniki - tylko $8 \%$ respondentów udzieliło odpowiedzi twierdzącej w stosunku do $88 \%$ tych, którzy nie zgodzili się z proponowanym stwierdzeniem (CBOS, 2016).

Rysunek 3. Opinie o funkcjonowaniu systemu opieki zdrowotnej z 2014 i 2016

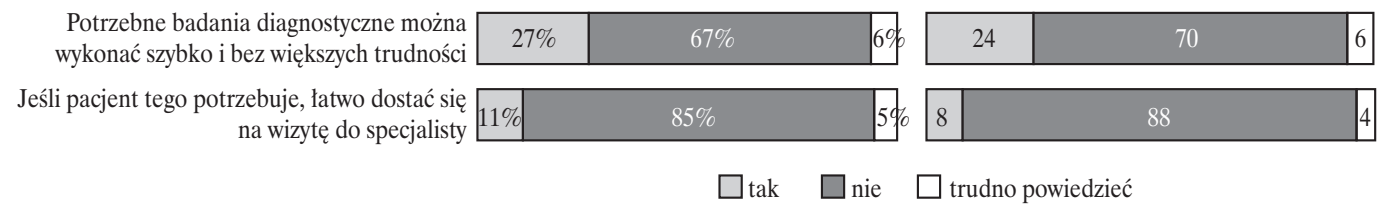

Źródło: CBOS, 2014, s. 2; CBOS, 2016, s. 4.

Natomiast w przypadku wariantu: czy potrzebne badania diagnostyczne można wykonać szybko i bez większych trudności, w 2014 tylko 27\% ankietowa- 
nych udzieliło odpowiedzi pozytywnej, a dwa lata później było ich o 3 punkty procentowe mniej.

Wyniki tych badań potwierdza raport NIK. Nawet wzrost nakładów pieniężnych na służbę zdrowia w Polsce i programy jej naprawy, nie rozwiązały problemu dostępu do świadczeń. Koszty poniesione przez NFZ w 2015 roku były wyższe o 4,4 mld zł i oscylowały w granicach kwoty 67 mld zł. Mimo to kolejki oczekujących pacjentów na niektóre świadczenia znacząco się wydłużyky (Zawadka, 2016).

Przyjrzymy się kilku skrajnym przykładom. Na wizytę w poradniach endokrynologicznych w 2015 roku oczekiwało o 12\% mniej pacjentów w porównaniu do poprzednich lat. Lecz długość pozostawania świadczeniobiorcy w kolejce nie spadła, a wręcz się wydłużyła ze 143 dni do 164 dni (rysunek 4).

Lista czekających pacjentów na przyjęcie na oddział chirurgii urazowoortopedycznej wydłużyła się o 0,5\% z 124144 do 124801 świadczeniobiorców, a czas oczekiwania wzrósł z 107 do 129 dni (o 20,6\%). Sytuacja nie wygląda lepiej także w przypadku świadczeń rehabilitacyjnych, gdzie kolejka oczekujących wydłużyła się z 286 do 348 dni.

Niestety, niektórzy decydenci, zajmujący się ochroną zdrowia w Polsce, raczej wolą marginalizować tę kwestię. Na stronie Konsultanta Krajowego w Dziedzinie Otorynolaryngologii można przeczytać, że: „na podstawie otrzymanych informacji od konsultantów wojewódzkich należy z satysfakcją odnotować, że dostępność do świadczeń medycznych jest dość dobra [...] Należy zaznaczyć, że oczekiwania pacjentów na świadczenia zdrowotne realizowane w ramach hospitalizacji wahają się od kilku miesięcy, do około 3 lat" (Skarżyński, 2015).

Rysunek 4. Liczba osób oczekujących i mediana średniego rzeczywistego czasu oczekiwania do poradni endokrynologicznych w latach 2013-2015, „przypadki stabilne”

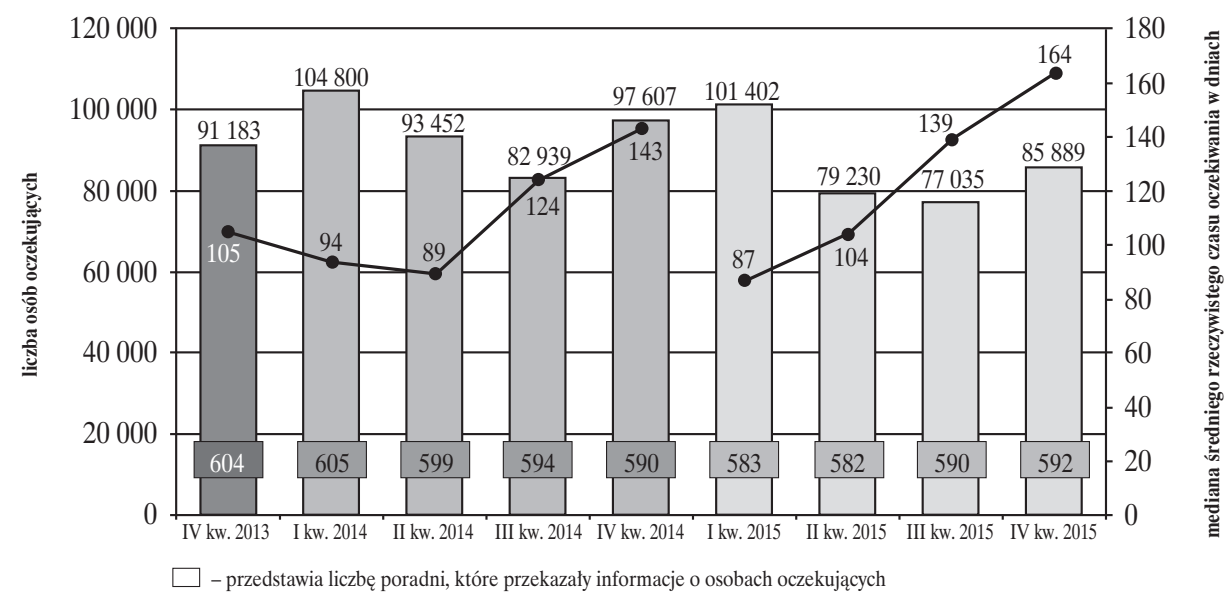

Źródło: NIK, 2016, s. 19. 
Nowocześnie funkcjonujące państwo, które nie może zapewnić pełnej dostępności świadczenia usług powinno korzystać z możliwości, jakie daje mu zglobalizowany świat, wysyłając swoich obywateli m.in. na zagraniczne leczenie. Lecz czy takie rozwiązanie sprawdzi się w polskich warunkach?

\section{Polski obywatel na leczeniu zagranicznym}

Polski pacjent, chcąc leczyć się poza granicami kraju zawsze stanie przed wyborem jednego wariantu $\mathrm{z}$ wachlarza trzech możliwości, $\mathrm{tj}$.:

- leczenie ze środków prywatnych, z których pokrywa się koszt całej usługi;

- leczenie refundowane za zgodą NFZ;

- leczenie w ramach dyrektywy transgranicznej.

Świadczenie bezpłatnej opieki zdrowotnej w nagłych wypadkach jest możliwe w krajach UE/EFTA za okazaniem tzw. Europejskiej Karty Ubezpieczenia Zdrowotnego i przysługuje każdemu jej posiadaczowi w placówkach publicznej opieki zdrowotnej, lecz nie mieści się w zakresie turystyki medycznej, gdyż nie ma charakteru dobrowolnego i nie jest głównym celem wyjazdu.

Rysunek 5. Możliwości leczenia dla polskiego pacjenta za granicą

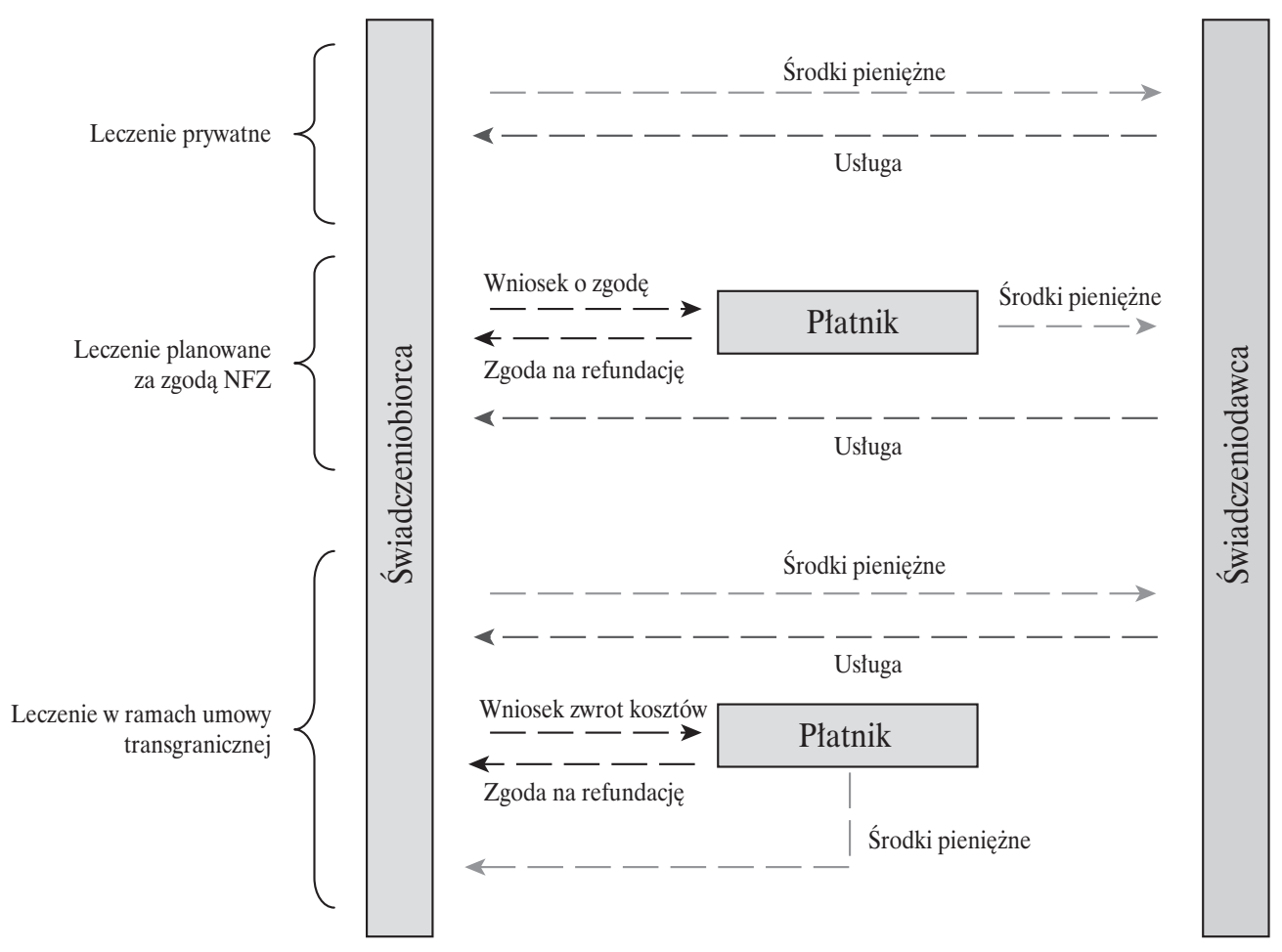

Źródło: opracowanie własne. 
Koncentrując się na leczeniu refundowanym przez NFZ pierwsza możliwość dotyczy tzw. świadczeń planowanych, czyli ściśle określonego i przewidywanego zakresu usług zdrowotnych, wymagający uprzedniej zgody. W myśl ustawy o świadczeniach opieki zdrowotnej leczenie takie poza granicami kraju obejmuje:

- usługi, których nie wykonuje się w Polsce;

- gdy przewidywany czas wykonania świadczenia przekracza dopuszczalny okres oczekiwania świadczeniobiorcy w kraju;

- zabiegi zawarte w tzw. wykazie świadczeń wymagających uprzedniej zgody.

Decyzję (przed leczeniem) o refundacji tego typu usługi podejmuje dyrektor właściwego wojewódzkiego oddziału NFZ na wniosek pacjenta, jeżeli jest to świadczenie, którego nie wykonuje się w kraju - niezbędne też jest uzyskanie zgody Prezesa NFZ.

W 2015 roku Narodowy Fundusz Zdrowia wydał 173 decyzji (z czego: 149 pozytywnych, 22 odmownych i 5 umorzeń), obejmujących planowane leczenie lub badania diagnostyczne poza granicami kraju. Dotyczyły one wyłącznie zabiegów, które nie są możliwe do wykonania w kraju (rysunek 6). Ogólna wartość tych świadczeń szacowana była na kwotę około $34 \mathrm{mln}$ zł (Pęcherz, 2016).

Rysunek 6. Zakresy świadczeń, w których Prezes NFZ wydał w 2015 roku decyzje pozytywne na planowane leczenia poza granicami kraju

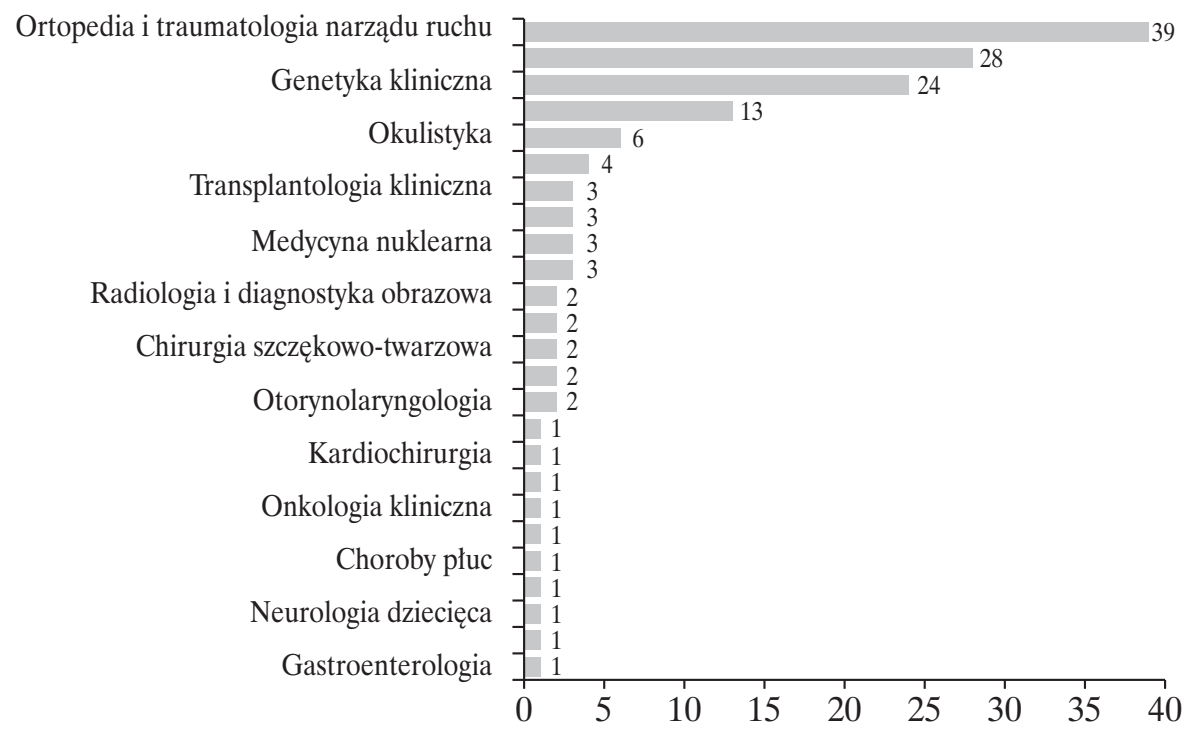

Źródło: Jacyna, 2016, s. 203. 
Drugim rozwiązaniem, które może wykorzystać polski świadczeniobiorca jest leczenie w ramach dyrektywy transgranicznej. Kilka lat temu (w 2014 roku) polski rząd przyjął dyrektywę Unii Europejskiej nr 2011/24/UE z dnia 9 marca 2011 roku w sprawie stosowania praw pacjentów w transgranicznej opiece zdrowotnej (Dz.Urz. UE L 88 z 4 kwietnia 2011 r., s. 45), która umożliwia polskiemu pacjentowi dostęp do świadczeń zdrowotnych w innych krajach członkowskich UE w placówkach (prywatnych i państwowych) zbiorowej opieki medycznej. Wprowadzenie tego rozwiązania miało za zadanie „urzeczywistnić działania Unii Europejskiej w zakresie zapewnienia wysokiego poziomu ochrony zdrowia ludzkiego" (zob. Narodowy Fundusz Zdrowia, 2017).

Z transgranicznej opieki medycznej może skorzystać każdy pacjent mający prawo do świadczeń opieki zdrowotnej finansowanych ze środków publicznych. Przed wyjazdem za granicę nie musi on informować o swoim leczeniu, ani uzyskać zgody od krajowych instytucji. Świadczeniobiorca za usługę medyczną w innym kraju członkowskim UE, płaci z własnych środków, ale po powrocie do kraju może ubiegać się o zwrot kosztów od NFZ. Ważną kwestią jest fakt, że refundację można otrzymać wyłącznie w zakresie leczenia, które jest objęte tzw. koszykiem świadczeń gwarantowanych. Kwota wypłaconych środków świadczeniobiorcy jest obliczana na podstawie cennika państwa, którego jest obywatelem. Ewentualną różnicę $\mathrm{w}$ wycenach pokrywa pacjent $\mathrm{z}$ własnego budżetu. Ponadto, zgodnie z przyjętą dyrektywą, ośrodek specjalistyczny do którego zamierza udać się świadczeniobiorca może wymagać, aby spełnił on takie same wymogi dopuszczające do leczenia, jak w kraju, w którym ma prawo do świadczeń zdrowotnych, czyli np. posiadać skierowanie od lekarza rodzinnego. Lecz powstaje pytanie, jak duża liczba Polaków wie o takiej możliwości?

W 2015 roku Komisja Europejska opublikowała specjalne badanie przeprowadzone na liczbie ponad 27 tys. respondentów, pochodzących ze wszystkich państw członkowskich UE, które sprawdzało wiedzę obywateli UE odnośnie do znajomości swoich praw w kontekście nieodpłatnego leczenia poza granicami kraju. Badani otrzymali trzy warianty dotyczące ich praw do otrzymania świadczeń medycznych w innych krajach UE. Mieli wybrać te, które były prawdziwe. Dwa z nich były poprawne: masz prawo do korzystania z opieki medycznej w innym kraju UE, a środki pieniężne, które wydateś, zostanq zwrócone przez wtaściwy organ ds. zdrowia w twoim kraju; drugi wariant dotyczył tego, że masz prawo otrzymać kopię dokumentacji medycznej od swojego lekarza, jeśli chcesz podjać leczenie w innym kraju UE. Natomiast wariant nieprawdziwy: nie możesz zrealizować recepty otrzymanej od swojego lekarza w innym kraju UE.

Ponad połowa Polaków wie o możliwości leczenia w innych krajach UE w ramach umowy transgranicznej. Aczkolwiek $34 \%$ respondentów nie umiało 
wybrać żadnego z przedstawionych wariantów. Ponadto, porównując te wartości do wyników obywateli innych krajów UE stopień naszej wiedzy pozwolił na zajęcie przez Polskę ósmego miejsca od końca (rysunek 7).

Rysunek 7. Mam możliwość zwrotu kosztów leczenia przeprowadzonego w innym kraju UE

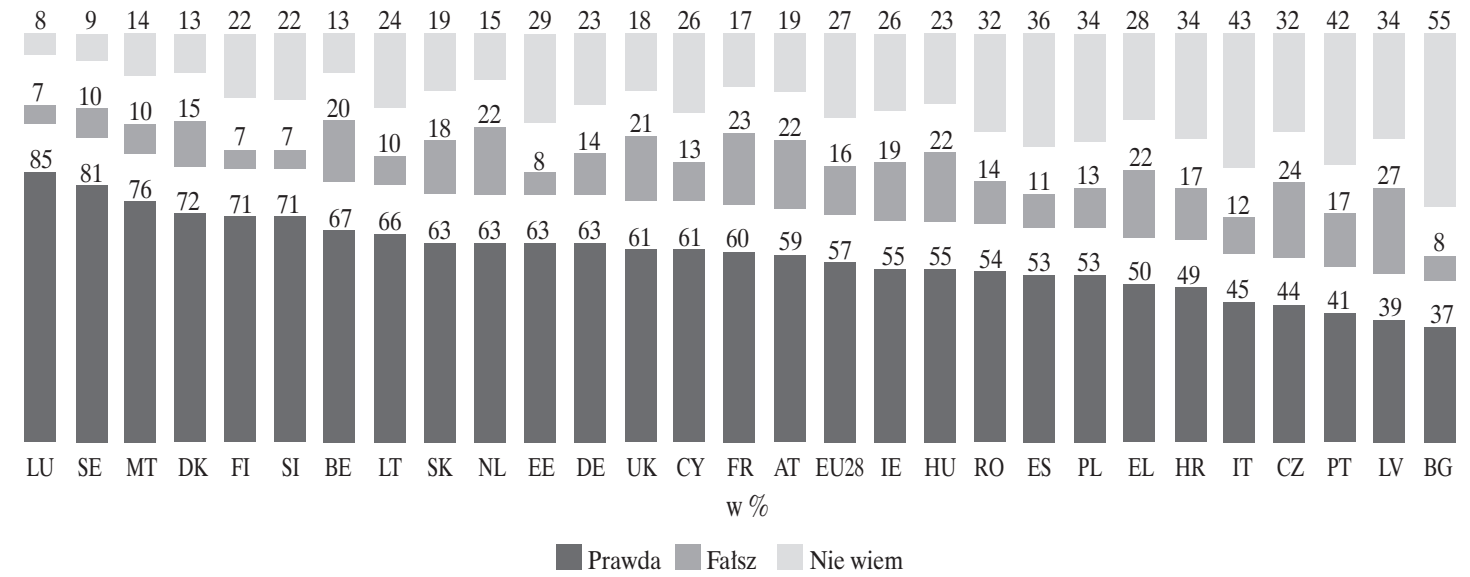

Źródło: European Commission, 2015, s. 10.

Polacy mają względnie wysoką wiedzę na temat prawa otrzymania kopii swojej dokumentacji medycznej od lekarza w kraju, jeśli chcą leczyć się poza jego granicami. Wybór prawidłowego wariantu to $67 \%$ wszystkich udzielonych odpowiedzi. Generalnie w państwach UE jest widoczna duża świadomość w tym zakresie. Wynik uzyskany przez mieszkańców Polski nie jest zły, ale na tle odpowiedzi udzielanych przez innych respondentów wydaje się mało zadowalający (rysunek 8).

Rysunek 8. Mam możliwość otrzymania kopii dokumentów od swojego lekarza, gdy chcę leczyć się za granicą w innym kraju UE

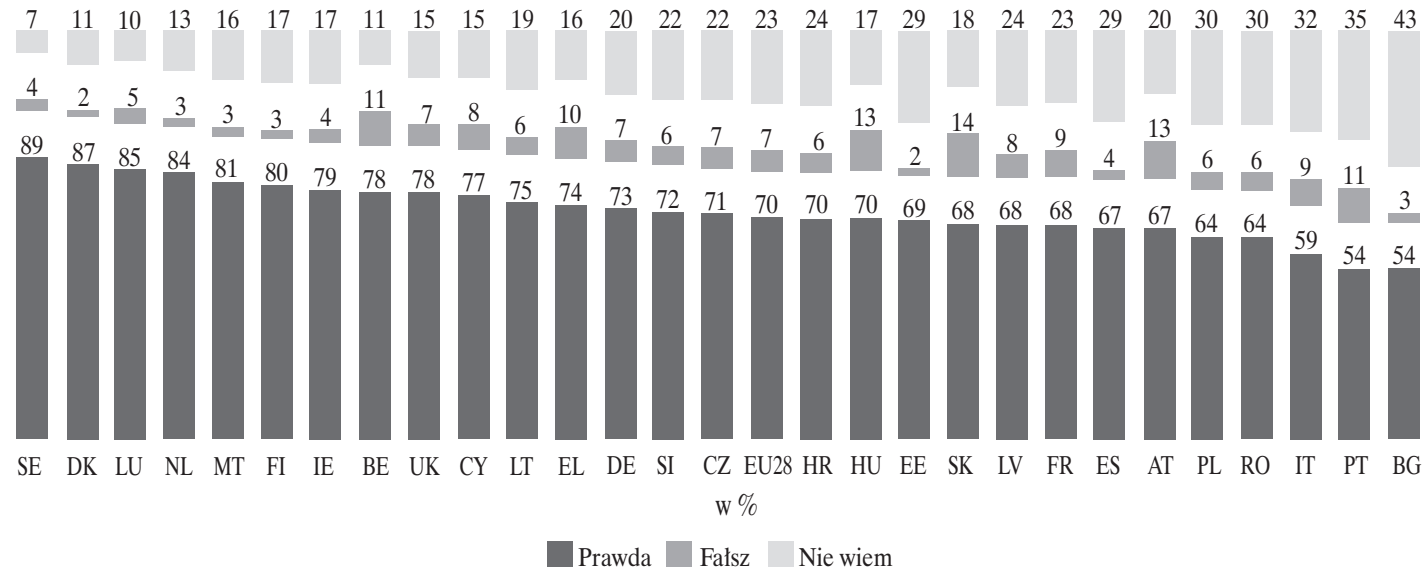

Źródło: European Commission, 2015, s. 11. 
Mniej niż trzech respondentów z dziesięciu spośród wszystkich obywateli UE wie, że receptę otrzymaną od swojego lekarza w kraju może zrealizować poza jego granicami. Podobnie sytuacja kształtuje się w Polsce. Tylko 21\% Polaków wybrało prawidłowy wariant odpowiedzi. Podobnie, jak w przypadku powyższych pytań, Polska zajmuje jedno z ostatnich miejsc wśród krajów UE (rysunek 9).

Rysunek 9. Nie mogę zrealizować recepty otrzymanej od swojego lekarza w innym kraju UE

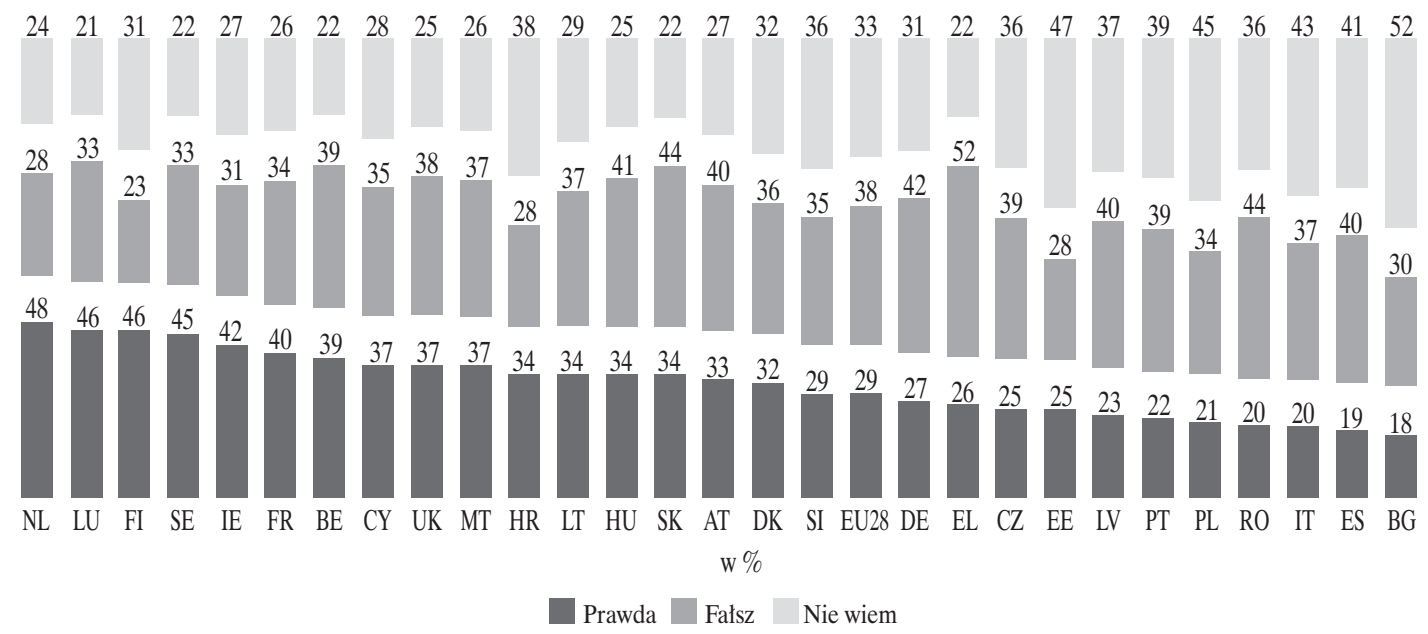

Źródło European Commission, 2015, s. 11.

Rysunek 10. Obywatele UE, którzy udzielili poprawnej odpowiedzi na przynajmniej dwa z trzech zadanych pytań (w \%)

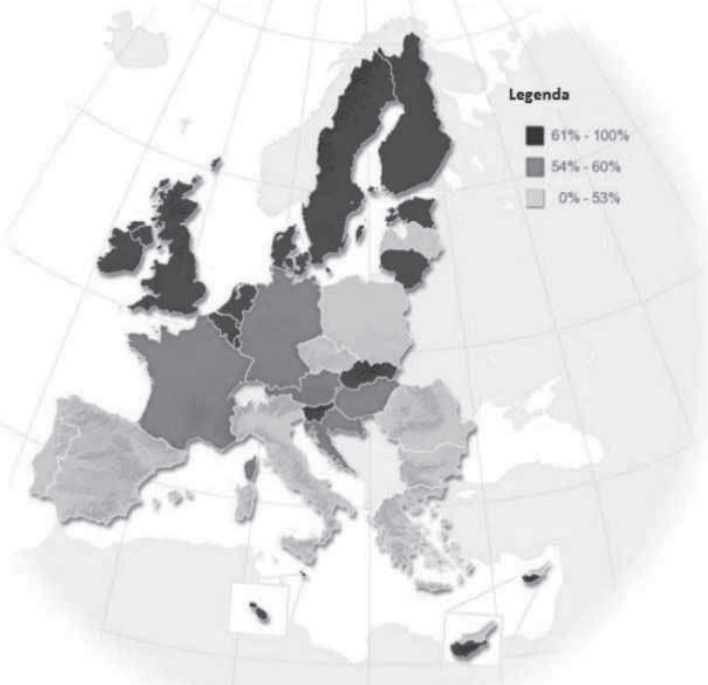

Źródło: European Commission, 2015, s. 12. 
Reasumując, rysunek 10 przedstawia proporcje respondentów, którzy udzielili przynajmniej dwóch poprawnych odpowiedzi spośród trzech zadanych pytań. Jeśli pominiemy pewne wyjątki, widoczny jest wyraźny podział geograficzny. Można przyjąć założenie, że jakość rozumiana, jako wysokie wyniki krajowego leczenia pacjentów częściowo pokrywa się z odpowiednią informacją na temat możliwości wyjazdu za granicę w celach medycznych. Dane te uwidaczniają, że polski obywatel nie dysponuje odpowiednią wiedzą o swoich prawach dotyczących możliwości wyjazdu w celach medycznych do innego kraju członkowskiego UE.

Pomimo niedoskonałej informacji w 2015 roku do wojewódzkich oddziałów NFZ wpłynęło 4872 wniosków dotyczących zwrotu kosztów świadczeń udzielonych naszym obywatelom poza granicami Polski (kraje UE). Kwota do zwrotu z nich wynikająca kształtowała się na poziomie 17741 922,46 zł. Na rysunku 11 można zauważyć (ogólną) tendencję rosnącą liczby składanych wniosków. Tylko miesiące sierpień, maj i czerwiec wykazywały pewne załamanie trendu.

Rysunek 11. Liczba wniosków o zwrot kosztów świadczeń udzielonych w innym państwie członkowskim UE w 2015 roku w poszczególnych miesiącach oraz kwota wnioskowana do zwrotu

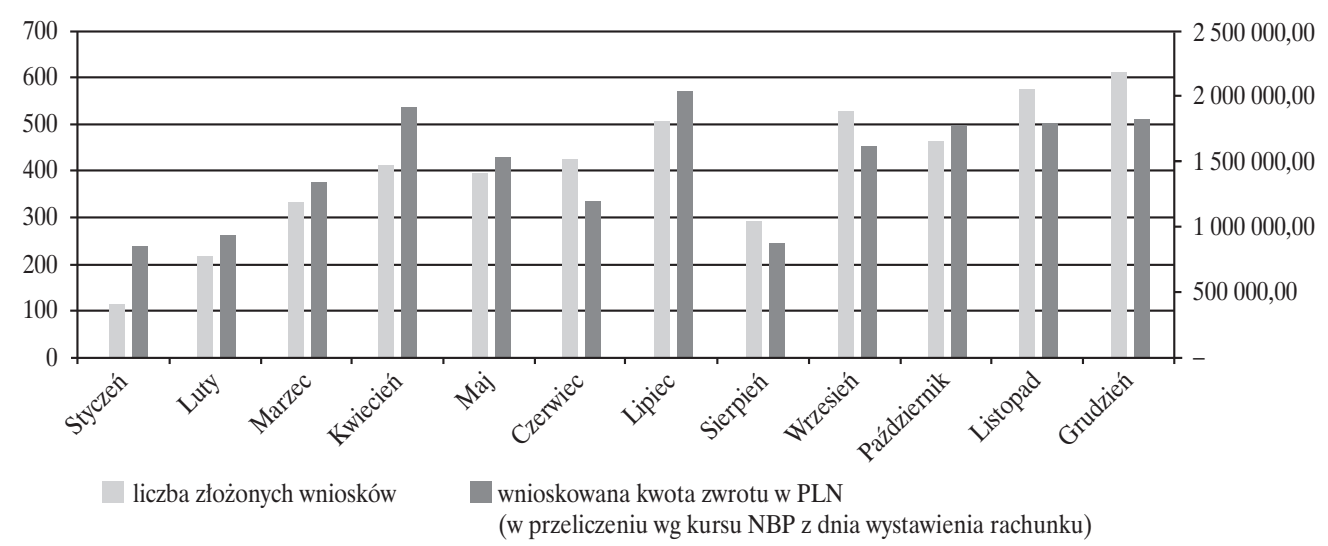

Źródło: Jacyna, 2016, s. 200.

Narodowy Fundusz Zdrowia w 2015 roku zakończył postępowania dotyczące 4100 wniosków ${ }^{2}$, z czego ponad $91 \%$ spraw rozpatrzono pozytywnie. Koszty świadczeń, które zostały zaakceptowane opiewały na łączną kwotę 9272145,76 zł. Jest to niewielka kwota pieniężna w stosunku do środków finansowych, jakie zostają co roku przeznaczane na leczenie krajowe (tabe-

2 W 2015 roku były przyjmowane również wnioski dotyczące zwrotu kosztów na podstawie art. 42b, obejmujące leczenie dokonane w 2014 roku. 
la 1). Jednak - prawdopodobnie - na przestrzeni kolejnych lat wydatki na zagraniczne leczenie będą rosły.

Decyzji odmownych dotyczących zwrotu poniesionych wydatków było około $2 \%$. Do najczęstszych przyczyn wydania negatywnych postanowień należały: ubieganie się o „zwrot kosztów świadczeń, które nie spełniały wymogów określonych w art. 42b ust. 1, 10-12" oraz brak odpowiednich dokumentów, tj. np. skierowanie. Średnia kwota zwrotu kosztów świadczenia w 2015 roku wyniosła 2 477,75 zł (Jacyna, 2016, s. 200).

Tabela 1. Liczba spraw dotyczących zwrotu kosztów świadczeń udzielonych w 2015 roku w podziale na sposób zakończenia sprawy

\begin{tabular}{|l|c|c|}
\hline \multicolumn{1}{|c|}{ Sposób zakończenia postępowania } & Liczba wniosków & Udzial \% \\
\hline $\begin{array}{l}\text { Decyzja pozytywna w sprawie zwrotu kosztów } \\
\text { (art. 42d ust. 1 ustawy o świadczeniach }\end{array}$ & 3747 & 91,40 \\
\hline $\begin{array}{l}\text { Decyzja o odmowie zwrotu kosztów } \\
\text { (art. 42d ust. 2 ustawy o świadczeniach) }\end{array}$ & 82 & 2,00 \\
\hline Decyzja o umorzeniu postępowania & 28 & 0,68 \\
\hline Pozostawienie sprawy bez rozpoznania & 5 & 5,63 \\
\hline Postanowienie o odmowie wszczęcia postępowania & 6 & 0,12 \\
\hline Odesłanie do właściwego oddziału & 1 & 0,15 \\
\hline Wycofanie wniosku przez stronę & 4100 & 0,02 \\
\hline ŁĄCZNIE & & 100,00 \\
\hline
\end{tabular}

Źródło: Jacyna, 2016, s. 200.

Tabela 2. Kwoty zwrotu poniesionych kosztów świadczeń w 2015 roku - według rodzaju świadczenia

\begin{tabular}{|l|c|c|}
\hline Rodzaj świadczeń opieki zdrowotnej & Łączna kwota zwrotów w PLN & Udział \% \\
\hline Ambulatoryjna opieka specjalistyczna & 51677,11 & 0,63 \\
\hline Leczenie stomatologiczne & 1197,02 & 0,02 \\
\hline Leczenie szpitalne - chemioterapia & 49399,90 & 0,60 \\
\hline Leczenie szpitalne - oddziały & 7877571,79 & 95,53 \\
\hline Lecznictwo uzdrowiskowe & 1451,31 & 0,02 \\
\hline Podstawowa opieka zdrowotna & 103,9 & 0,00 \\
\hline Refundacja leków & 3627,58 & 0,04 \\
\hline Świadczenia kontraktowane odrębnie & 188163,77 & 2,28 \\
\hline Świadczenia wysokospecjalistyczne & 56986,79 & 0,69 \\
\hline Zaopatrzenie w wyroby medyczne & 15760,00 & 0,19 \\
\hline ŁĄCZNIE & 8245939,17 & 100,00 \\
\hline
\end{tabular}

Źródło: Jacyna, 2016, s. 201. 
Najczęstszym zabiegiem, jaki wykonywali polscy turyści medyczni w 2015 roku była operacja usunięcia zaćmy. Świadczenie to uwidoczniono w 3133 wnioskach. Zdarzało się, że jeden dokument o zwrot kosztów dotyczył nawet dwóch zabiegów. Dlatego też Narodowy Fundusz Zdrowia dokonał refundacji aż 3271 operacji tego typu. Średnia kwota, która została zwrócona pacjentowi, oscylowała wokół wartości 2210,93 zł. Przeciętna opłata za sam zabieg wykonany za granicą w przypadku standardowego leczenia wynosi od 2500 zł do 3500 zł. Ostateczna kwota, jaką trzeba zapłacić za usunięcie zaćmy jest uzależniona od skomplikowania przypadku i wyboru soczewki. Jeśli jest wymagane wszczepienie np. wieloogniskowej soczewki torycznej (równoczesna korekta astygmatyzmu) - koszty są wyższe. Wtedy za zabieg należy zapłacić od około 4900 do $5500 \mathrm{zł}$. W związku z tym finansowanie z NFZ wynosi w takim przypadku około $40-44 \%$.

Znaczna część wniosków o zwrot kosztów dotyczyła świadczeń otrzymanych przez polskich turystów medycznych w Czechach $(87,65 \%)$, których wypłacona kwota wyniosła ponad $6 \mathrm{mln}$ zł. Ponadto, pacjenci często wybierali także usługi niemieckich szpitali i przychodni. Wnioski obejmujące nabycie świadczeń w tym kraju stanowiły 14,88\% całkowitej ich liczby. Kwota zwrotu kosztów w tym przypadku kształtowała się na poziomie ponad $1 \mathrm{mln}$ zł.

Tabela 3. Liczba dokonanych zwrotów oraz kwoty zwrotu wypłacone w 2015 roku - według państw członkowskich

\begin{tabular}{|l|c|c|c|c|}
\hline \multicolumn{1}{|c|}{ Państwo UE } & Liczba zwrotów & Udział \% & Lączna kwota zwrotów w PLN & Udzial \% \\
\hline Austria & 6 & 0,18 & 19754,78 & 0,24 \\
\hline Belgia & 2 & 0,06 & 372,05 & 0,00 \\
\hline Cypr & 1 & 0,03 & 2207,37 & 0,03 \\
\hline Czechy & 2917 & 87,65 & 6882663,60 & 83,47 \\
\hline Francja & 6 & 0,18 & 86560,39 & 1,05 \\
\hline Hiszpania & 5 & 0,15 & 6450,60 & 0,08 \\
\hline Holandia & 2 & 0,06 & 228,4 & 0,00 \\
\hline Niemcy & 381 & 11,45 & 1225739,99 & 14,86 \\
\hline Rumunia & 4 & 0,03 & 4674,14 & 0,06 \\
\hline Słowacja & 3 & 0,12 & 13157,85 & 0,17 \\
\hline Wielka Brytania & 3328 & 100,00 & 3130,00 & 0,04 \\
\hline ŁĄCZNIE & 202 & 8245939,17 & 100,00 \\
\hline
\end{tabular}

Źródło: Jacyna, 2016, s. 202. 
Rysunek 12. Liczba złożonych wniosków i dokonanych zwrotów oraz kwoty zwrotu wypłacone w 2015 roku - według oddziałów wojewódzkich NFZ

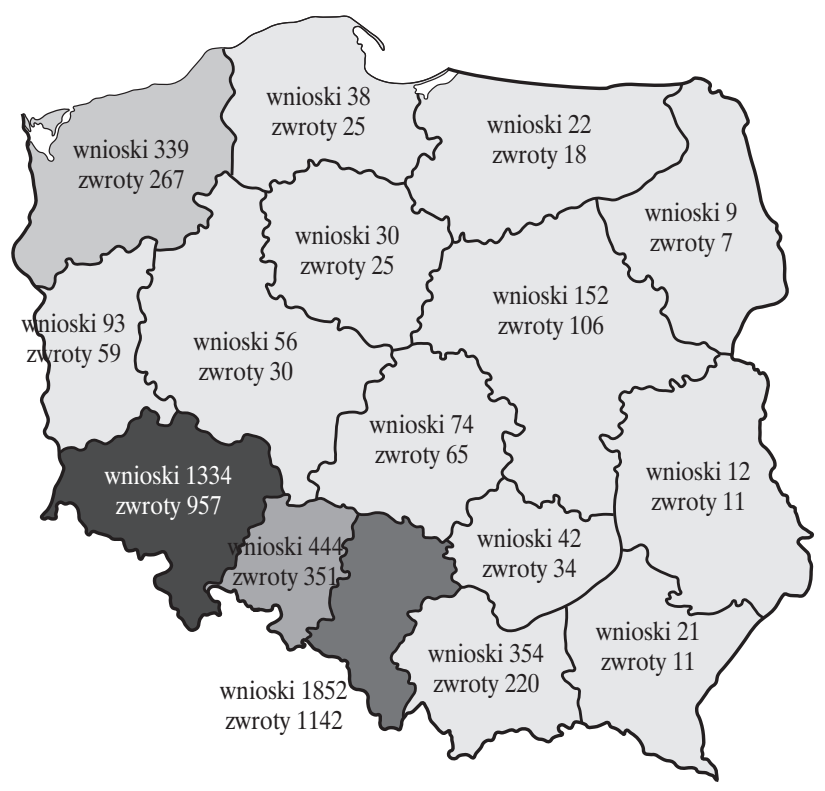

Łączna kwota zwrotów w złotych polskich

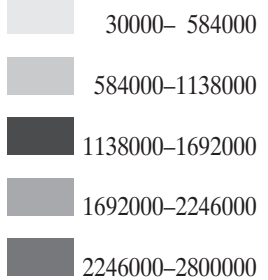

Źródło: Jacyna, 2016, s. 202.

Najwięcej wniosków dotyczących zwrotu kosztów na podstawie art. 42b ustawy o świadczeniach zostało złożone w śląskim oddziale NFZ - aż 1852 dokumentów, z czego wypłat dokonano w 1142 przypadkach. Ich wartość oscylowała w granicach $2 \mathrm{mln}$ zł, co stanowiło 32,78\% całkowitej wielkości kosztów poniesionych przez Narodowy Fundusz Zdrowia na ten cel (Jacyna, 2016).

Jak można zaważyć, na rysunku 12, polska wyjazdowa turystyka medyczna dotyczy głównie województw skrajne zlokalizowanych - szczególnie w pasie przygranicznym z Czechami. Zainteresowanie zabiegami w tym kraju jest bardzo duże. W celu dopełnienia informacji na temat popularności tego kraju odwołamy się do statystyk Google ${ }^{3}$ Trends. Hasło „operacja zaćmy Czechy” od momentu wejścia w życie dyrektywy transgranicznej może poszczycić się niesłabnącą popularnością (rysunek 13).

3 Można przyjąć, że dane te charakteryzuje ujęcie procentowe w stosunku do całkowitej liczby wyszukiwań w Google na świecie lub regionalnie - w zależności od ustawień. Jednak taka interpretacja bywa problematyczna. Dlatego lepszym wyjściem będzie traktowanie tych wartości w kategoriach punktowych, gdzie najwyższa popularność danego wyrażenia jest równa 100, a najniższa 0 . Nie jest to bezwzględna liczba operacji. Gdy wyszukiwanie obejmuje wyrażenie, wyniki prezentują statystykę dotyczącą wszystkich żądanych słów w dowolnej kolejności z zachowaniem np. odmiany przez przypadki w języku polskim. Pomijane są synonimy i błędy ortograficzne. Zdarza się także, że połączenia kilku słów zamknięte w cudzysłowie uwidaczniają różne wyniki w stosunku do tych samych wyrażeń z jego pominięciem (HOPE_Publications, 2015). 
Rysunek 13. Zainteresowanie terminem „operacja zaćmy Czechy” od 1 stycznia 2013 do 1 stycznia 2017 roku

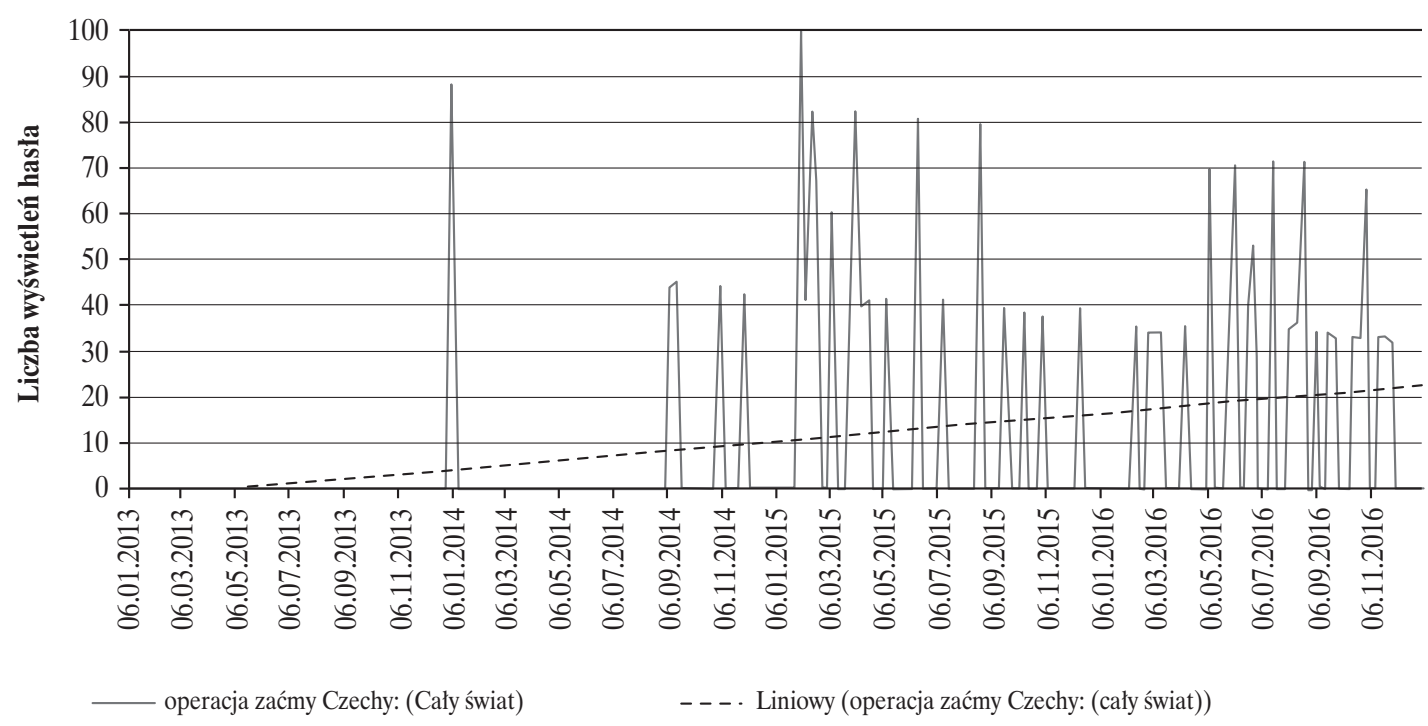

Źródło: opracowanie własne na postawie Google Trends.

\section{Wyjazdowa turystyka medyczna Polaków a gospodarka}

Pojawia się więc pytanie, czy turystyka medyczna może okazać się szansą na poprawę stanu systemu ochrony zdrowia w Polsce?

W ekonomii ochrony zdrowia przyjmuje się, że utrata zdrowia (choroba) jest pewną formą czynnika generującego koszty, szczególnie te o charakterze bezpośrednim i pośrednim.

Koszty bezpośrednie można podzielić na dwie grupy: koszty medyczne (np. wydatki poniesione na zakup sprzętu medycznego i leków, środki przeznaczane na płace personelu służby zdrowia, a także pieniądze, które trzeba wydać na pobyt jednostki w zakładzie zbiorowej opieki medycznej) oraz koszty niemedyczne (np. wydatki związane: ze stosowaniem specjalnej diety, transportem do placówki medycznej oraz opieką nieformalną). Do głównych składników kosztów bezpośrednich zalicza się: opiekę zdrowotną i administrację, leczenie następstw i skutków ubocznych, czas i ból pacjenta oraz czas rodziny, czas i niedogodności dostawcy usług (Hermanowski, Drozdowska, 2013).

Drugą kategorię stanowią koszty pośrednie, które można ogólnie określić, jako utratę lub ograniczenie zdolności do pracy w wyniku choroby. Analiza ekonomiczna powinna uwzględniać wszystkie kanały oddziaływania choroby na podmioty ekonomiczne nie tylko te, które bezpośrednio związane są ze służ- 
bą zdrowia. W ujęciu pośrednim choroba jest jedną z przyczyną zmniejszenia zasobu pracowników w gospodarce. Powoduje ona sytuację, w której jednostka często nie jest zdolna do pracy, co może przekładać się na obniżoną efektywność przedsiębiorstwa, w którym znalazła zatrudnienie. Zmniejszona liczba przepracowanych godzin przez pracownika może wpływać na wielkość dochodów jego gospodarstwa domowego oraz obniżenie środków przeznaczanych na konsumpcję. Połączenie takich czynników, jak: utrata (częśsi) zarobków, niższy poziom konsumpcji w gospodarstwie domowym oraz spadek efektywności produkcji w przedsiębiorstwie wiąże się ze zmniejszeniem wysokości odprowadzanych podatków i składek oraz zwiększeniem transferów wypłacanych przez państwo na rzecz gospodarstw domowych. Efektem finalnym jest pogorszenie się sytuacji sektora finansów publicznych (EY, 2013).

Wielu autorów rozszerza kategorię kosztów pośrednich do tzw. kosztów społecznych, która wówczas dotyczy także strat ogólnie przyjętego dobrobytu społecznego, wynikającego z pogorszenia jakości życia, czy też traconego czasu wolnego oraz zmniejszonej konsumpcji dóbr i usług (Hermanowski, Drozdowska, 2013, s. 13-30). Turystyka medyczna może pomóc w ograniczeniu skutków choroby w tym zakresie.

Koncentrując się na głównych faktach należy stwierdzić, że po pierwsze, polski system ochrony zdrowia nie radzi sobie z tak dużą liczbą osób chorych. Czekając w długich kolejkach oprócz (w większości przypadków) istnienia możliwości pogorszenia się stanu zdrowia jednostki, gospodarka traci w pewnym sensie siły wytwórcze. Patrząc wyłącznie na sferę ekonomiczną i wspomniane wyżej koszty pośrednie - chory pracownik jest nieefektywny. Przez brak zdrowia nie wykonuje obowiązków na miarę swoich możliwości, wykorzystuje system zwolnień lekarskich - w efekcie traci na tym zarówno on sam, jak i przedsiębiorca oraz budżet państwa Teraz odwróćmy tę sytuacje - obywatel nie czeka w kolejce, pobierając świadczenie o wysokiej jakości za granicą, np. w Czechach czy Niemczech. Płaci za usługę z własnych środków i otrzymuje zwrot kosztów, ale do wysokości kwoty, którą i tak budżet państwa (NFZ) wypłaciłby w przypadku leczenia krajowego. Jednostka taka staje się w pełni efektywna w dużo krótszym czasie niż miałoby to miejsce w przypadku pobierania świadczenia w kraju.

W badaniach udowodniono, że zdrowie obywateli w znacznym stopniu przekłada się na sytuację gospodarczą kraju. Analizując ten problem warto przyjrzeć się opisowi matematycznemu, który został zaproponowany przez Marca Suhrcke'a (Hermanowski, Drozdowska, 2013). 


$$
\mathrm{Y}=\mathrm{A} * \mathrm{~F}(\mathrm{Kh} \mathrm{L})
$$

gdzie:

$\mathrm{Y}$ - produkcja/PKB,

A - wskaźnik TFP (całkowitej wydajności),

$\mathrm{F}$ - funkcja produkcji,

$\mathrm{K}$ - kapitał fizyczny,

$\mathrm{L}$ - praca,

h - kapitał ludzki lub jakość pracy.

Wzrost wskaźnika TFP jest uzależniony od efektywności łączenia czynników produkcji. W związku z tym poziom zdrowia będzie miał tu znaczenie w kontekście naszych działań biznesowych i badawczych. Choroba wpływa negatywnie na aktywność zawodową. Jednostki zdrowsze charakteryzuje najczęściej lepsza wydajność pracy, a tym samym wyższa produktywność w każdej przepracowanej godzinie. Tomasz Hermanowski i Aleksandra Drozdowska twierdzą - na podstawie badań - iż duża część dzisiejszego bogactwa narodów ma swoje źródła w poprawie zdrowia w przeszłości. Wynika z tego, że zdrowie determinuje wzrost gospodarczy (Hermanowski, Drozdowska, 2013).

Oczywiście, ochrona zdrowia nie służy wyłączenie celom ekonomicznym. Leczenie ludzi wynika także - nazwijmy to ogólnie - z pobudek moralnych. Powyższy opis miał tylko charakter przykładowy. To nie pieniądze są w tym wszystkim najważniejsze. Opieka zdrowotna z założenia powinna być dostępna dla wszystkich potrzebujących pomocy. Obecnie polski pacjent leczący się w kraju ma do wyboru dwie możliwości - oczekiwać w kolejce, lub ją ominąć poprzez nabycie usług medycznych prywatnie, co dyskryminuje osoby mniej zamożne. Zasada równej dostępności do świadczeń medycznych zaczyna mieć coraz mniejsze znaczenie. Należy przyznać, że także turystyka medyczna nie jest dla wszystkich, gdyż dotyczy głównie osób, mających dość duże środki własne, pozwalające na pokrycie kosztów świadczeń i transportu. Dodatkowo, konieczność dłuższej podróży, nieznajomości kraju, czasem także języka i kultury w miejscu docelowym - mogą zniechęcać wielu potencjalnych pacjentów oraz zawężać grupę wiekową turystów medycznych. Przykładowo, osoby starsze raczej nie zdecydują się na taki wyjazd. Jednak umożliwienie podróży za granicę zainteresowanym tym rozwiązaniem obywatelom spowoduje zmniejszenie kolejek w kraju, przyczyniając się tym samym do poprawy zdrowia innych grup, które na taki wyjazd nie mogą sobie pozwolić. Odbywa się to bez zmian o naturze systemowej.

Zauważmy, że zagraniczne wyjazdy Polaków to także podróże po jakość otrzymywanych usług. Jeśli istnieje możliwość leczenia w placówkach lepiej 
wyspecjalizowanych, które posiadają zaawansowane technologie i wysokiej klasy specjalistów, to państwo dbające o swoich obywateli powinno stwarzać szanse do tego typu leczenia. Wysoka jakość wykonanej usługi przełoży się na ograniczenie ryzyka nawrotu choroby oraz dłuższą efektywność jednostki zarówno w obszarze społecznym, jak i ekonomicznym.

Ponadto, promocja wyjazdowej turystyki medycznej może przyczynić się do poprawy efektywności także świadczeniodawców. Zarówno instytucje publiczne, jak i przedsiębiorstwa prywatne zetkną się z problemem nowej konkurencji - już nie tylko na rynku krajowym, ale także międzynarodowym. Pacjent z założenia wybierze lepszą dla siebie ofertę pod względem jakościowym oraz cenowym. Placówki państwowe mogą zostać zmuszone do poprawy jakości oferowanych usług, a firmy prywatne do obniżenia cen. W przypadku drugiego wariantu - świadczenia staną się bardziej dostępne dla części osób, które obecnie nie mogą korzystać z takiej możliwości.

Wadą rozwoju wyjazdowej turystyki medycznej jest sytuacja, w której instytucje planujące wydatki w obszarze ochrony zdrowia tracą kontrolę nad środkami przeznaczanymi na leczenie. Tłumacząc to nieco jaśniej - osoba pobierająca świadczenie medyczne w kraju (w pewnym stopniu) ograniczona jest limitami, tzn. może wykonać zabieg w jednostce państwowej, która dysponuje wolnymi środkami, przeznaczonymi na ten cel lub czekać w kolejce. Jest to przeniesienie kosztu w przyszłość. Wyjazdy na zagraniczne leczenie nie są w tym zakresie limitowane. Jeśli wniosek o zwrot kosztów jest poprawnie wypełniony i nie posiada wad natury formalnej - NFZ powinien wydać pozytywną decyzję o zwrocie środków. Gdy „podróże po zdrowie” uzyskają skalę masową - prawdopodobnie - w sposób znaczący przyczynią się do obciążenia budżetu publicznego. Oczywiście, rozwiązanie tego problemu nie będzie łatwe, lecz jest możliwe. Przecież import usług medycznych można (w przypadku Polski) z powodzeniem rekompensować eksportem, który wykorzystałby zasoby placówek medycznych niemożliwe do użycia w ramach niskich kontraktów z NFZ. Wtedy bilans handlowy będzie oscylował w pobliżu zera.

Niestety, turyści medyczni, którzy zdecydują się na zagraniczne leczenie, mogą być narażeni na szereg niebezpieczeństw, z których najpoważniejszym jest błędna informacja. Kluczowym czynnikiem dzięki któremu turystyka medyczna mogła zaistnieć stało się wykorzystanie Internetu. Nawet najlepsze kliniki byłyby pozbawione rzeszy klientów, gdyby nie posiadały odpowiedniej reklamy w globalnej sieci. Usługi komercyjne stanowią serce turystyki medycznej. W związku z tym, dostęp do zasobów sieciowych i informacji jest tu nieoceniony. Internet stał się łącznikiem pomiędzy świadczeniodawcami a konsumentami. Oferuje on szereg funkcjonalności, do których należą 
m.in. marketing, opinie oraz dzielenie się doświadczeniami przez klientów na forach dyskusyjnych dotyczących danych placówek medycznych, czy też prostotę $\mathrm{w}$ dystrybucji usługi z zastosowaniem systemów, tj. CRM ${ }^{4}$. Jednak, należy w tym miejscu zwrócić uwagę na pewną kwestię - jakość otrzymywanych informacji. W ostatnim czasie powstaje wiele obaw wobec treści zamieszczanych w Internecie dotyczących turystyki medycznej. Strony www są stosunkowo tanie w konfiguracji i uruchomieniu, a ich treść nie jest regulowana. W związku z tym oferty takie mogą być niedoskonałe lub nie zawsze zgodne z prawdą - nierzetelne, co przekłada się na niebezpieczeństwo „konsumpcji” usług, które stanowią ich przedmiot. Zawsze trzeba wyważyć atrakcyjność tego typu rozwiązań z ryzykiem, które mogą ze sobą nieść (Lunt i in., 2011).

\section{Podsumowanie}

Reasumując, Polska jest krajem, który ma problem z dostępnością do świadczeń zdrowotnych. Rozwiązanie w postaci turystyki medycznej o charakterze wyjazdowym wydaje się być interesującą alternatywą. Jednak jej rozwój może budzić wiele wątpliwości - szczególnie w obszarze kosztów. Jest to w pewnym sensie ominięcie przyjętych rozwiązań systemowych. Pacjenci, wyjeżdżając na zagraniczne leczenie mogą korzystać z zabiegów medycznych na „koszt państwa” w sposób nieograniczony (z wyjątkiem konieczności wyboru usługi z koszyka świadczeń gwarantowanych i posiadania prawa do leczenia ze środków publicznych). Dopóki wiedza polskich obywateli w tym zakresie jest niewielka - wydatki w tej sferze są marginalne. Jednak, jeśli skalę omawianego zjawiska zacznie cechować masowość - rozwiązanie to może okazać się problematyczne dla budżetu państwa, który - już w tym momencie - jest znacząco ograniczony. Jednocześnie ważne jest także dobro pacjenta, który powinien mieć możliwość leczenia w sposób właściwy (godny). Jest to wybór pomiędzy odpowiednim gospodarowaniem środkami finansowymi a moralnością. Powstaje zatem pytanie, co jest ważniejsze? Oczywiście polski obywatel ma prawo także do korzystania w kraju z usług prywatnych, które są lepsze jakościowo i pozbawione kolejek. Jednak, czy w ten sposób nie zmusza się go do płacenia za swoje zdrowie dwa razy? - państwowo (w postaci składki, z której i tak nie korzysta) i prywatnie. Wyjeżdżając na zagraniczne leczenie przynajmniej w sposób częściowy odzyskuje zapłacone wcześniej pieniądze od NFZ, co nie byłoby możliwe w przypadku prywatnego leczenia krajowe-

4 CRM (Customer Relationship Management) na potrzeby artykułu rozumiany jest jako system informatyczny, służący do zarządzania relacjami z klientem, który wspiera i automatyzuje pracę na linii klient - przedsiębiorstwo. 
go. Dodatkowo, nie zajmując kolejki przyczynia się do jej skrócenia, dając możliwość pomocy innym osobom, które - z różnych przyczyn - nie mogą sobie pozwolić na podróż zagraniczną, a sam staje się dużo szybciej efektywny (zdolny do pracy) nie tylko dla siebie, ale także dla gospodarki. Pozostaje jeszcze jedna kwestia do omówienia, czyli sytuacja drugiej strony systemu ochrony zdrowia - świadczeniodawców. Czy rozwój turystyki medycznej wpłynie negatywnie na jednostki publicznej i prywatnej opieki zdrowotnej? Zapewne nie uzyskamy jednoznacznej odpowiedzi na to pytanie. Kontrakty z NFZ są ograniczone, tzn. w ramach określonej kwoty (bez zadłużenia) można wykonać daną (nieprzekraczalną) liczbę usług. Nie miejmy złudzeń, że w przyszłości zaistnieje sytuacja, w której (przez turystykę medyczną) pojawi się w szpitalach i przychodniach znacznie mniejsza liczba pacjentów niż ta wynikająca z kontraktu, gdyż duża część naszych obywateli jest zmuszona do leczenia w kraju, ze względu na swoją sytuację materialną lub życiową. W tym przypadku turystyka medyczna nie jest zagrożeniem. Jednak jeśli zwrócimy uwagę na jednostki prywatne świadczące usługi zdrowotne - problem wydaje się być oczywisty. Tego typu przedsiębiorstwa (w szczególności zlokalizowane w zachodnim i południowym pasie przygranicznym) zetkną się z zupełnie nowym typem konkurencji - zagranicznymi jednostkami, które zazwyczaj są na dużo wyższym poziomie rozwoju pod względem: nowoczesnych metod leczenia, podejścia do pacjenta i szeroko rozumianej jakości świadczonych usług. Powstanie sytuacja, w której firmy te zostaną zmuszone do poprawy poziomu swojej oferty, lub obniżenia ceny. Zarówno w pierwszym, jak i w drugim przypadku w efekcie skorzysta na tym pacjent, a także (w pierwszym wariancie) jednostki publiczne, które (nawet w przypadku niechęci) będą musiały podążać za tą jakością. Może wtedy zmodernizowane polskie kliniki sprawią, że lekarze i pielęgniarki będą chętniej pracować w kraju. Pewne jest jedno - aby silnie rozwijać turystykę wyjazdową na masową skalę należy skoncentrować się także na tej o charakterze przyjazdowym. Tylko w ten sposób możliwe jest zabezpieczenie przed bardzo wysokim obciążeniem budżetu.

Należy przyznać, że turystyka medyczna (dla licznego grona osób) charakteryzuje się zapewne taką samą liczbą wad, jak i zalet. Jednak jej powstanie wynika z wyzwań obecnych czasów. Niestety, nawet jeśli jesteśmy jej zagorzałymi przeciwnikami - ona i tak będzie się rozwijać coraz szybciej. Ideą ojców założycieli Unii Europejskiej, której jesteśmy członkiem, było stworzenie regionu bez granic. Turystyka medyczna idealnie wpisuje się w ten sposób myślenia. W związku z tym grzechem byłoby niewykorzystanie tej szansy. 


\section{Bibliografia}

EY (2013). Medtodyka pomiarów kosztów pośrednich w polskim systemie ochrony zdrowia. Warszawa: EY.

CBOS (2014). Opinie o funkcjonowaniu systemu opieki zdrowotnej nr107/2014. Warszawa: CBOS.

CBOS (2016). Opinie o funkcjonowaniu systemu opieki zdrowotnej nr113/2016. Warszawa: CBOS.

European Commission (2015). Patients' rights in cross-border healthcare in the European Union; Eurobarometer 425. Brussels: European Commission.

Hermanowski, T., Drozdowska, A. (2013). Ocena wartości życia i zdrowia, pomiar korzyści związanych z technologiami medycznymi, rodzaje kosztów w opiece zdrowotnej. W: T. Hermanowski (red.). Szacowanie kosztów spotecznych choroby $i$ wplywu stanu zdrowia na aktywność zawodowa $i$ wydajność pracy. Warszawa: Wolters Kluwer Polska.

HOPE_Publications (2015). Medical Tourism. Belgium: HOPE Publications.

Jacyna, A. (2016). Sprawozdanie Narodowego Funduszu Zdrowia za rok 2015. Warszawa: Narodowy Fundusz Zdrowia.

Lunt, N., Smith, R., Exworthy, M., Green, S.T., Horsfall, D. i Mannion, R. (2011). Medical Tourism: Treatments, Markets and Health System Implications: A scoping review. Paris: OECD Publications Service.

Narodowy Fundusz Zdrowia (2017). Leczenie w innym państwie członkowskim UE wynikające $z$ dyrektywy transgranicznej. Pobrano z lokalizacji Krajowy Punkt Kontaktowy do spraw transgranicznej opieki zdrowotnej: http://www.kpk.nfz.gov.pl/pl/leczenie-w-innym-panstwie.html (dostęp: 20.12.2017).

NIK (2016). Realizacja zadań przez Narodowy Fundusz Zdrowia w 2015 roku. Warszawa: Najwyższa Izba Kontroli.

Nojszewska, E. (2011). Funkcjonowanie systemu ochrony zdrowia w Polsce na tle wybranych krajów europejskich. W: Ryć K., Skrzypczak, Z. Ochrona zdrowia na świecie. Warszawa: Wolters Kluwer.

Pęcherz, T. (2016). Funkcjonowanie dyrektywy o transgranicznej opiece zdrowotnej w warunkach polskich. I Krakowski Kongres Turystyki Medycznej. Kraków.

Pochrzęst-Motyczyńska, A. (2016). NFZ. Pacjenci nie odwołują umówionych wizyt. Kolejki coraz dłuższe. Gazeta Wyborcza z 28 kwietnia.

Skarżyński, H. (2015). Konsultant Krajowy w Dziedzinie Otorynolaryngologii. Pobrano z lokalizacji: Ocena dostępności świadczeń zdrowotnych: http://konsultant-krajowy.pl/inicjatywy/ ocena-dostepnosci-swiadczen-zdrowotnych/ (dostęp: 20.12.2017).

Zawadka, G. (2016). Kolejki do lekarzy specjalistów coraz dłuższe. Rzeczpospolita z 24 listopada. 